\title{
GEOMORPHOSITES AND GEOTOURISM IN BUCHAREST CITY CENTER (ROMANIA)
}

\author{
Laura Comănescu, Alexandru Nedelea, Gabriel Stănoiu \\ Faculty of Geography, University of Bucharest, Romania
}

Manuscript received: April 29, 2017

Revised version: July 17, 2017

\begin{abstract}
Comănescu L., Nedelea A., StănoiU G., 2017. Geomorphosites and geotourism in Bucharest city center (Romania). Quaestiones Geographicae 36(3), Bogucki Wydawnictwo Naukowe, Poznań, pp. 51-61. 8 figs, 3 tables.

ABSTRACT: The present paper aims at inventorying the geomophosites in Bucharest as well as introducing geotouristic itineraries that take into account the long-time developed high value cultural heritage of the area. The process included several stages: studying Bucharest's relief and cultural- historical elements with tourist value from existing bibliography, cartographic methods (aerial photos and different editions of topographic maps), as well as the information gathered from field investigations; identifying and inventorying geomorphosites, assessing the population's opinion about geoheritage (geomorphosites) and its capitalization in tourism activities, 100 questionnaires were applied; creating geotouristic itineraries and later promoting them. The most valuable and representative geomorphosites identified are: on Colentina Valley (the Plumbuita, Ostrov, Dobroeşti and Pantelimon hills) (aren't located in the study area), on Dâmboviței Valley (Cotroceni, Șerban Vodă, Mitropoliei, Spirii, Filaret and Arsenal hills, Țăcăliei, Procopoaiei, University terraces, Dâmbovița Meadow). The authors suggest two geotouristic itineraries that emphasize the relationship between the scientific, cultural, and historic elements as well as the human-nature report within the urban area.
\end{abstract}

KEY WORDS: geomorphosites, geotouristic itineraries, Bucharest, Romania

Corresponding author: Laura Comănescu, lauracomanescu@yahoo.com

\section{Introduction}

The city of Bucharest and the surrounding area of Romanian Plain have been the subject of numerous works of a historical, socio-cultural or tourist character, but fewer works of geographic nature. The first writings belong to Mihăilescu $(1915,1942)$ who illustrates the importance of the geographical location of the city, the main features of relief, as well as the relationship between its territorial extension and its capital function. Contributions dedicated to some components of the geographical environment are related to the climate (Dumitrescu 1971), geology (Liteanu 1952), hydrology (Cocoș 1999) and industry (Iancu 1977). In 1984, is published the first synthesis on the geography of the city of Bucharest (Posea, Ştefănescu 1984), emphasizing the relationship between natural and socio-human conditions in city's development and extension. So far, there are no works that address Bucharest's relief, its deep transformations suffered over time due to man and his activities, and that highlight the geomorphological heritage elements existing within this area.

In Romanian literature, the geomorphological heritage approach, namely of geomorphosites, is relatively recent, presenting either theoretical concepts (Ilieş, Josan 2007, Ilieş et al. 2009), or inventories and evaluation of geomorphosites in different areas (Comănescu, Dobre 2009, Comănescu et al. 2009, Comănescu, 
Nedelea 2010, Bâca 2011, Cocean, Surdeanu 2011, Comănescu et al. 2011b, Comănescu et al. 2012, Artugyan 2016, Cocean, Cocean 2017), their mapping (Comănescu et al. 2011a, Ilieș et al. 2011, Comănescu et al. 2013) or use in geotourism activities (Comănescu et al. 2009, Bâca, Schuster 2011, Gavrilă et al. 2011, Bâca 2012, Purice et al. 2013).

Andrășanu (1996) relates the existing legislation, the activities of non-governmental organizations in the field of geoheritage and the theoretical basis related to the conservation of the geological heritage in Romania. Grigorescu et al. (2003) establish the relationships between the conservation of the geological heritage and the regional development strategies. Andraşanu, Grigorescu (2012) draw a history of legislation related to the conservation of the geological heritage in Romania, presenting numerous case studies. Manoleli et al. (2003) are concerned with the evaluation of the inventoried geological sites to facilitate the selection of Natura 2000 Areas, focusing on their abiotic and ecological components.

After the year 2000, the scientific literature increased its efforts to establish a methodology to inventory (Reynard et al. 2007) and evaluate geomorphosites (Pralong 2005, Coratza, Giusti 2005, Bruschi, Cendrero 2005, Serrano, GonzalesTrueba 2005, Reynard et al. 2007, Pereira, Pereira 2010). Reynard (2009) has made a first synthesis for geomorphosites evaluation and established a series of common characteristics for the evaluation methods, classifying them into direct evaluation (subjective) and indirect evaluation (objective) methods. At the same time, he emphasized the role of general context within which the evaluation is made as well as of the selected criteria and subcriteria.

Within a study with an obvious methodological character connected to the inventory of geomorphosites for the Gruyère - Pays-d'Enhaut national park, Bussard and Reynard (2014) underlined the degree of protection for geomorphosites and the relation between them and tourism. Reynard et al. (2016) propose a new multiphase method which comprises, among other elements, the selection phase, the stakeholder valorization and the usage characteristics. The selected geomorphosites must be representative both in space and time.
Contributions about geomorphosites located in urban areas (Pica et al. 2016) and their valorization through geotourism are associated to different cities which include a valuable geologic-geomorphologic heritage (Rodrigues et al. 2011, Pica et al. 2017).

Geomorphosites located in urban areas, many of them with heritage value, must also be preserved for future generations, according to the principles of geoconservation (Pereira 2017). The role of geotourism is to promote geodiversity and geoheritage through geomorphosites (Pereira 2017). For the development of geotourism it is necessary to create, design and popularize different urban (geotourist) routes, their attractive interpretation and inclusion in tourism activities, adding to other different forms of tourism already taking place in these areas (Pinto et al. 2011). At international level (Rodrigues et al. 2011) the initiative in Montreal (Canada) that was the first city which in 2007 joined the Geotourism Charter of National Geographic Society is relevant.

Although contributions related to geoheritage are diversified, in Romanian literature there are no papers aimed at studying geomorphosites from an urban space. In this sense, our intention is to approach the inventory of geomorphosites in the city of Bucharest (its central sector) and the relationship between these and the anthropic tourist sites. This relationship highlights the link between natural and cultural heritage, both of which are components of the total heritage of a territory (Ilieş, Josan 2009). The ultimate goal is the creation, analysis and subsequent popularization of two representative geotourism routes for Bucharest.

\section{Study area}

The city of Bucharest is located in the southern central part of Romania, $64 \mathrm{~km}$ north of the Danube River, $250 \mathrm{~km}$ west of the Black Sea and $100 \mathrm{~km}$ south of the Carpathians, at the intersection of parallel $44^{\circ} 26^{\prime}$ north latitude with the meridian of $26^{\circ} 06^{\prime}$ eastern longitude (Fig. 1A). It has a total area of $228 \mathrm{~km}^{2}(0.8 \%$ of Romania's surface).

Within the city the altitudes decrease from the northwest to the southeast, the maximum being $96.3 \mathrm{~m}$ (referring to the entire plain, maximum is 

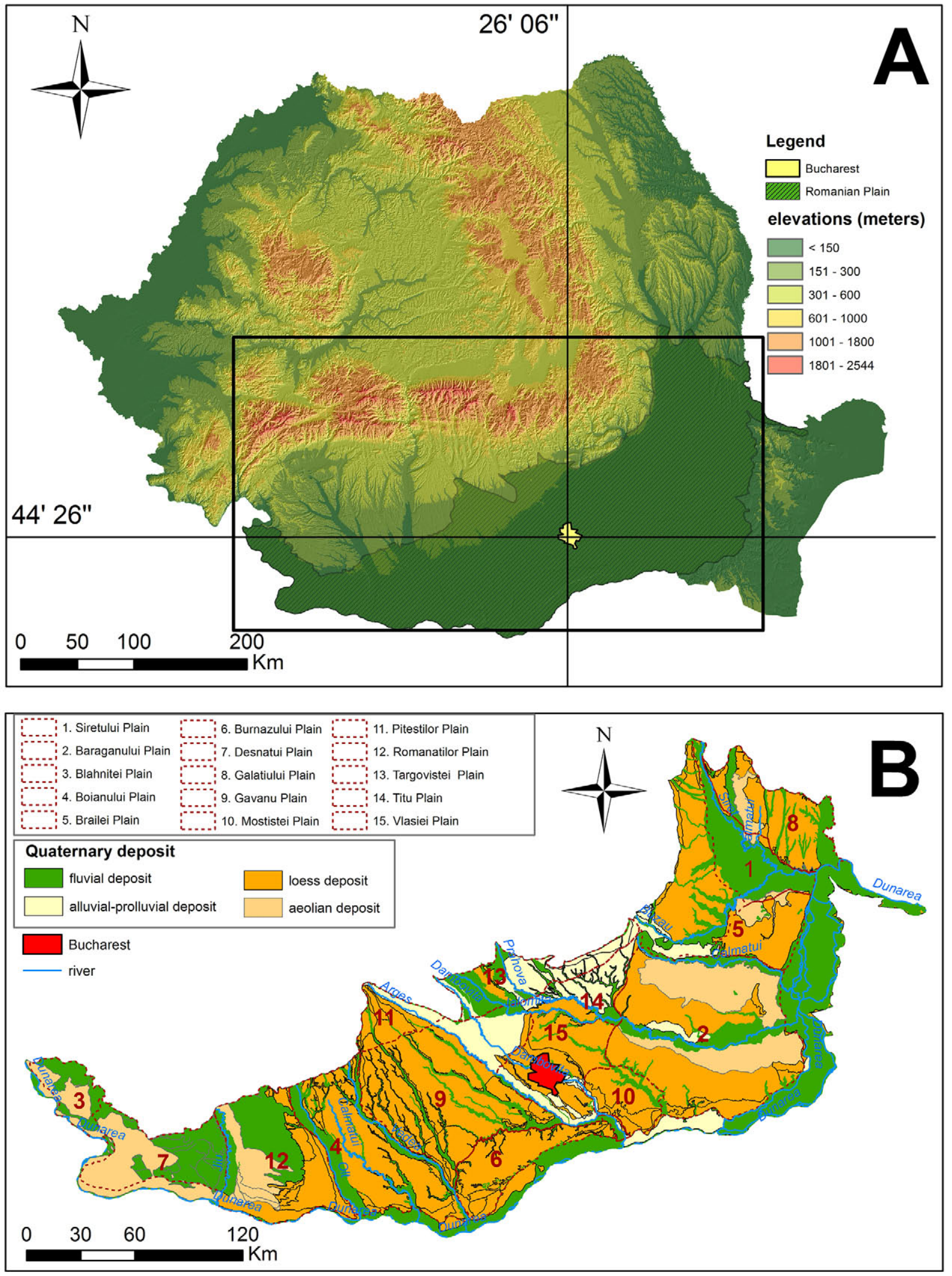

Fig. 1. A.The geographical position of Bucharest city in Romania. B. The Romanian Plain - geological features (Grecu et al. 2012) and subunits. 
of 115-120 $\mathrm{m}$ in the northwest part) and the minimum of 57 m (in Dâmbovița meadow), the average altitude being $79 \mathrm{~m}$. Over $50 \%$ of city's surface is part of the hypsometric step of 80-100 m, the drainage density being $1-1.5 \mathrm{~km} / \mathrm{km}^{2}$, and the slopes are below $3^{\circ}$. The altitudes in the western part of the city are higher than in the east due to uplift movements in the Pleistocene (Enciu et al. 2008).

From the structural point of view, Bucharest's territory overlaps the Valah section of the Moesian Platform. The sedimentary superstructure belongs to four sedimentation cycles: Paleozoic (about $6500 \mathrm{~m}$ thick), Permian-Triasic (about $5000 \mathrm{~m}$ thick), Liasic-Cretaceous (about $3500 \mathrm{~m}$ ) and Badenian-Pleistocene (thicknesses over $1500 \mathrm{~m}$ ) (Ionesi 1994).

The Bucharest Plain formed through the gradual retreat of the Getic lake and then accumulation of gravels (named „The Colentina”), sands and gravels with lenticular clay intercalation, followed by loess and loess deposits during Late Pleistocene (thickness 10-20 m) (Fig. 1B) (Ionesi 1994, Posea, Ștefănescu 1984). The Plain completely rose above sea level at the beginning of the Holocene, and was later sculptured by multiple generations of valleys, and then transformed by anthropic activity.

Bucharest's relief is mainly represented by Bucharest Plain (part of Vlăsia Plain) (Fig. 1B) with its subunits (Pantelimon - Băneasa Field, Colentina Field, Cotroceni - Văcărești Field, Colentina Valley, Dâmbovița Valley) (Fig. 2A) (Posea, Ștefănescu 1984, Enciu et al. 2008).

The most important subunits within the city are Dâmbovița and Colentina valleys, typical plain valleys, with a high degree of anthropization.

Dâmbovița valley is formed in loess, it is asymmetrical with the right bank high (10-15 $\mathrm{m}$ ) and the left bank low (from $4-5 \mathrm{~m}$ to $8 \mathrm{~m}$ ).

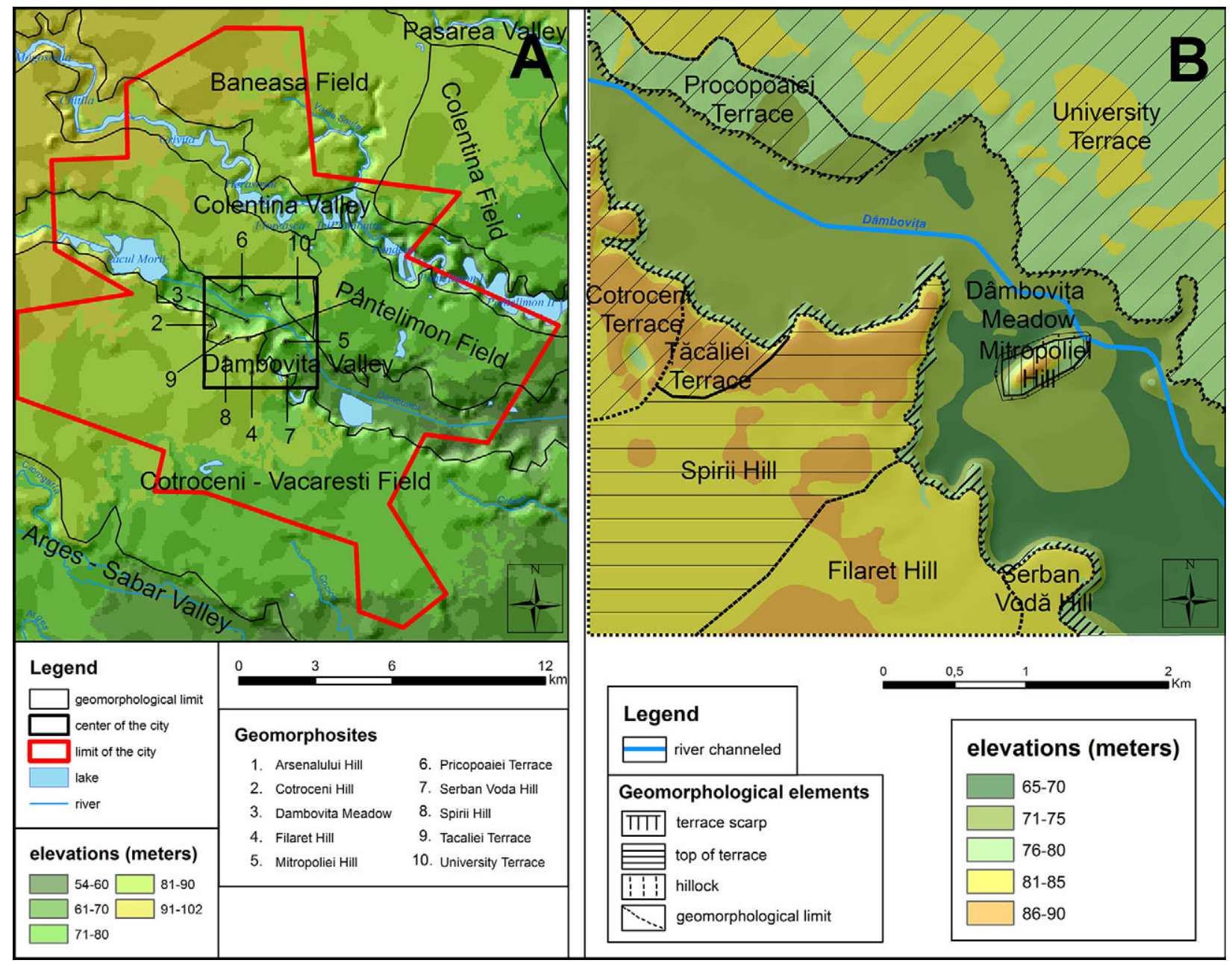

Fig. 2. Bucharest city.

A. The subunits of Vlăsia Plain. B. Geomorphological sketches. 


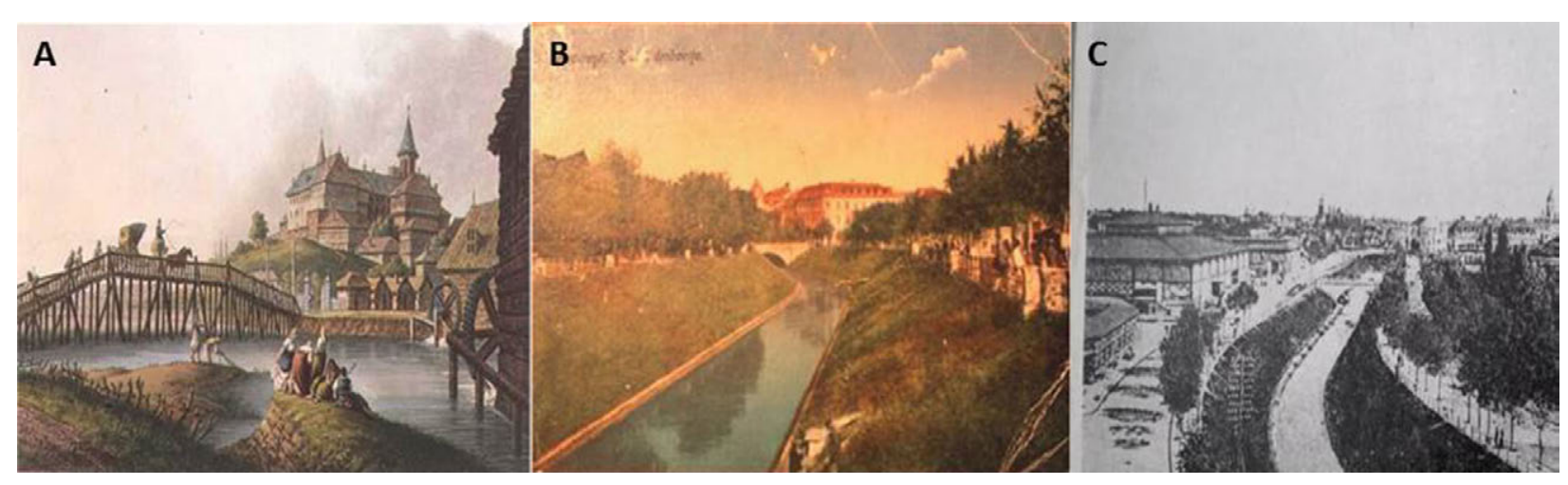

Fig. 3. The Dâmbovița valley before fitting.

A. Dâmbovița Valley in Dealul Spirii Area (after Mayer Luigi 1755-1803; Stematiu, Teodorescu 2012; www.proceedings.agir.ro); B. The morphology of Dâmbovița river bed after first fitting in 1880-1885 (Stematiu, Teodorescu 2012; www.proceedings.agir.ro; Archive); C. Dâmbovița valley in area between Mitropoliei Hill and Șerban Vodă Hill in 1927 (http:/ / calatorii.myfreeforum.ro/t426-raul-si-valea-dambovita; Archive).

It features a four-terraced system (known in geographic papers as $\mathrm{T}_{1}-\mathrm{T}_{4^{\prime}}$ with different regional names), well-personalized (predominantly on the left) (Grecu et al., 2012) (Fig. 2B).

It has been channeled and regularized (in several stages since the end of the $19^{\text {th }}$ century) and the mead microforms (springs, meanders, meanders points bars, islands, steep banks) have been modified except for some cut-off lobe hillocks (Mitropoliei Hill etc.) (Fig. 3).

Colentina valley is an asymmetric valley that has undergone significant changes in the construction of the labyrinth of lakes and their adjacent buildings. It is characterized by a high degree of meandering, low slope $(0.8 \mathrm{~m} / \mathrm{km})$ and the presence of well-developed meadows on both banks with widths ranging from 100-500 $\mathrm{m}$ to about $1.5 \mathrm{~km}$ (in the right of meanders in Plumbuita-Cernica sector). Because of the regularization works, the meadow was covered by the lakes' waters on significant sections, and there are several cut-off lobe hillocks like island shape such as Plumbuita, Ostrov, Dobroeşti and Pantelimon. There are two local terraces (2-4 $\mathrm{m}$ and 8-12 $\mathrm{m}$ ), which are not typical terraces but meander terraces (Posea Ştefănescu 1984).

According to Mihăilescu (1942), both in the case of Dâmbovița and Colentina rivers from the terraces or plain erosion witnesses were detached in the form of mounds or peaks.

The original relief was greatly modified by humans, especially in the last century, by: decreasing the slope of the terraces or river sides, constructing embankments and excavations for communication routes, regulating water courses against floods, the existence of negative relief microforms that were originally intended for the exploitation of construction materials, which were subsequently filled with waste or acquired other functions (parks, sport arenas) (Fig. 3) (Posea, Ștefănescu 1984, Enciu et al. 2008, Grecu et al. 2012).

\section{Methods}

The methodology that led to the realization of this paper has started from the current bibliographic referential (geological, geomorphological features, but also cultural-historical, literary or tourism geography), with adaptations to the particularities of the analyzed urban space. Several steps have been taken to achieve the proposed objectives. It also investigated the existing cartographic basis (1: 25,000 scale maps, 1: 5,000 plans, various cadastral plans and aerial images from 2003-2005 flights).

The next step was dedicated to field research, where geomorphosites were identified and located using the method developed by Reynard et al. (2007). A database was created in which the attributes that characterize the geomorphosite were introduced. This comprises the following elements: general data (name, location, type, property, topographic representation, photos); qualitative data about the scientific, ecologic, cultural, aesthetic value; the presence of some human made tourism attractions; the existence of some management measures. Selected geomorphosites were finally included within the proposed routes. 
Table 1. The applied survey on Bucharest city inhabitants.

\begin{tabular}{|c|c|c|}
\hline Chapter 1 . Data on subjects & $\begin{array}{l}\text { Chapter } 2 . \text { The data related to Bucha- } \\
\text { rest's relief }\end{array}$ & $\begin{array}{l}\text { Chapter } 3 \text {. Data on the proposed } \\
\text { tourist sites and routes }\end{array}$ \\
\hline $\begin{array}{l}\text { 1. Age: } \\
\text { - under } 20 \text { years } \\
\text { - 20-40 years } \\
\text { - } 40-60 \text { years } \\
\text { - over } 60 \text { years }\end{array}$ & $\begin{array}{l}\text { 1. What representative forms of relief } \\
\text { (geomorphosites) for Bucharest city } \\
\text { do you know? (open answer) }\end{array}$ & $\begin{array}{l}\text { 1. Which are the most important ele- } \\
\text { ments for tourism in Bucharest city? } \\
\text { - human made attractions } \\
\text { - natural elements } \\
\text { - the infrastructure }\end{array}$ \\
\hline $\begin{array}{l}\text { 2. Gender: } \\
\text { - male } \\
\text { - female }\end{array}$ & $\begin{array}{l}\text { 2. What value would you confer to } \\
\text { the above mentioned forms of relief? } \\
\text { - scientific } \\
\text { - cultural } \\
\text { - aesthetic } \\
\text { - economic }\end{array}$ & $\begin{array}{l}\text { 2. What should authorities do in } \\
\text { order to develop tourism activities in } \\
\text { Bucharest city? (open answer) }\end{array}$ \\
\hline $\begin{array}{l}\text { 3. Education: } \\
\text { - secondary education } \\
\text { - high school } \\
\text { - superior education }\end{array}$ & $\begin{array}{l}\text { 3. What changes were produced in } \\
\text { the relief of Bucharest city through } \\
\text { human activities? (open answer) }\end{array}$ & $\begin{array}{l}\text { 3. What tourism attractions should be } \\
\text { included in your opinion within the } \\
\text { Bucharest city tours? (open answer) }\end{array}$ \\
\hline $\begin{array}{l}\text { 4. The neighborhood you live in } \\
\text { (open answer) }\end{array}$ & & $\begin{array}{l}\text { 4. What is your opinion about } \\
\text { making some geotourism routes and } \\
\text { promoting materials? (open answer) }\end{array}$ \\
\hline
\end{tabular}

In order to know the opinion of Bucharest inhabitants about the geomorphological heritage and its capitalization in tourism, qualitative methods (questionnaires) were applied, being obtained data statistically processed and interpreted, the results being used in the creation of the geotourism routes. The applied questionnaire (Table 1) included 11 questions, either grid or open-answer, structured in three chapters: data on subjects, data related to Bucharest's relief, and data on the proposed tourist objectives and routes.

Chapter 1 - Data on subjects included identification elements related to age, gender and level of training (important component for the accuracy of responses) as well as their domicile.

Chapter 2 - The data related to Bucharest's relief aimed at establishing the landforms that are known to the inhabitants, how they perceive their value as well as data related to the transformations they have suffered in time, the relief of the city.

Chapter 3 - Data on the proposed tourist sites and routes started from the establishment of the most important tourist attractions, their location in relation to the relief forms, the necessity of introducing them in some routes and the ways of popularizing the proposed itineraries.

This is the first time the population is consulted on this issue (February-March 2017, several points in the city center), the sample chosen trying to meet the representativeness criteria (gender, age and level of training), being filledin 100 questionnaires, whose structure was previously presented. Certainly, a larger sample would have yielded more statistically significant results.

\section{Sample Structure}

Of the surveyed sample, $62 \%$ are women and $38 \%$ are men. The share of age groups is balanced: under 20 - 10\% (predominantly male); between 20-40 years - 33\% (predominantly women), 40-60 years - $47 \%$ (predominantly women), over $60-10 \%$ (predominantly men). The average age of respondents was 38.5 years (we consider that a higher average age would be more relevant given the period of time elapsed since the events of December 1989 linked to the existence of questions about the changes suffered by the relief during communism epoch). As a training level, only two categories were selected: high school $30 \%$ and higher education $-70 \%$.

The end of our approach is represented by the synthesis of the data from the previous stages and the creation of the geotourism routes covering both the geomorphosites situated in the central part of the city and the anthropic tourist sites related to them or in their proximity. The two routes were analyzed from the point of view of length, time required for scrutiny and visiting, the relief forms and the difficulty of the route. 


\section{Results and discussions}

\section{Geomorphosites}

On the background of plain relief, the morphogenetic action of Colentina and Dâmbovița rivers led to the emergence of specific relief forms, some of which could be considered geomorphosites. In this case, we mention: on Colentina valley: the Plumbuita, Ostrov, Dobroeşti, and Pantelimon hills (Fig. 2A) (no location in the study area); on Dâmboviței valley: Cotroceni, Uranus-Mihai Vodă, Șerban Vodă, Mitropoliei, Spirii, Movila Mare, Radu Vodă, Piscului, Filaret and Văcărești hills, Țăcăliei, Procopaiei, University terraces (Fig. 2B). Many of the terraces that dominate the meadow are called popular hills (Mihăilescu 1915).

In the analyzed area, ten geomorphosites, of fluvial origin, have been identified and localized (Table 2, Fig. 2B) with scientific, cultural and aesthetic value.

The geomorphosites located in the central part of the city, which are the best known by the population, will be analyzed, many of them encompassing an important cultural component, linked to anthropic tourist sites (cultural, historical, religious, artistic and architectural).

Cotroceni Hill is an extensive terrace of Dâmbovița River, which was formerly covered by Codrii Vlăsiei (a forest that was located on most of the territory on which the city is located). Here a monastery was built by the ruler Şerban Cantacuzino in the $17^{\text {th }}$ century, which was the core of the Royal Palace founded in 1888 by King Carol I (Giurescu 1966).

Țăcăliei Terrace is on the continuation of Cotroceni terrace, being also covered by Codrii
Vlăsiei. Here are a number of monuments such as Elena Doamna Hospice, Davilla Church, Anna Davilla's Statue,

Spirii Hill is a witness from an old terrace of Dâmbovița River On it was built in the $16^{\text {th }}$ century the Mihai Vodă Monastery (demolished in 1984 by the Communist regime).

The highest point of it, which advances as a spur to the river; it is called the Arsenalului Hill. Here, it was built the New Court (which became the Burn Court after the fire in 1812), and in 1860 by the Army Arsenal (the existing chapel being transformed into Army Dust Hall (Pulberăria Armatei). Currently, on the hill (and near in Uranus Hill) is the Palace of Parliament (House of People), whose construction began in 1984 (Giurescu 1966, Cantacuzino 1997).

Filaret Hill is a witness from a terrace of Dâmbovița, covered with vineyard until the end of the $19^{\text {th }}$ century. Today, there is Carol Park, inaugurated in 1906 with an area of 36 hectares (Bădăuță, Cicio-Pop 1935). The most important tourist attractions are: Cantacuzino Fountain (19 ${ }^{\text {th }}$ century, on the site of the former fountain of Filaret Metropolitan), the Roman Areas (built in 1906), Dimitrie Leonida Technical Museum (which was founded in 1909), the Mausoleum (built on the central plateau, built between 1959 and 1963, in front of it being the Tomb of the Unknown Hero), the Zodiac Fountain (inaugurated in 1935 by King Carol II) (Georgescu et al. 1966, Berindei, Bonifaciu 1978).

Șerban Vodă Hill is the extension of the Filaret Hill, witness from Dâmbovita terrace.

Mitropoliei (Patriarhiei) Hill is a hillock from the old meadow of Dâmbovița, on its slopes taking place creeping gravitational processes. It is an emblematic point of the city from the tourist,

Table 2. The geomorphosites situated in central area of București City.

\begin{tabular}{|c|c|c|c|c|}
\hline No. & Name of geomorphosite & Code & Type & Additional values \\
\hline 1. & Cotroceni Hill (Terrace) & Bfl01 & areal & Cultural \\
\hline 2. & Spirii Hill & Bfl03 & areal & Cultural \\
\hline 3. & Serban Vodă Hill & Bfl05 & areal & Cultural \\
\hline 4. & University Terrace & Bfl07 & areal & Aesthetic, cultural \\
\hline 5. & Arsenalului Hill & Bf09 & punctual & Cultural \\
\hline 6. & Țăcăliei Terrace & Bfl02 & areal & Cultural \\
\hline 7. & Filaret Hill & Bfl04 & area & Aesthetic, cultural \\
\hline 8. & Mitropoliei Hill & Bfl06 & punctual & Cultural \\
\hline 9. & Procopoaiei Terrace & Bfl08 & areal & Ecological \\
\hline 10. & Dâmboviței Meadow & Bf10 & areal & \\
\hline
\end{tabular}


cultural-historical and religious point of view, where the Romanian Patriarchate is located. In the $17^{\text {th }}$ century, the hill was owned by the rulers of Wallachia and was totally covered with vineyards. In the central part of the hill lies the Patriarchal Church (built in the $17^{\text {th }}$ century), in the west the old hermitages, in the southeast the Patriarchal Palace (built in the $17^{\text {th }}$ century), to the east the Paraclis (the most valuable piece of the whole complex founded in the $17^{\text {th }}$ century) and the Chamber of Deputies' Palace (founded in 1907, on the place of the former Divan Domnesc) and in north, the Bell Tower (dating from the $17^{\text {th }}$ century) (Ionescu 1938).

Procopoaiei Terrace is formed on a wide terrace of Dâmbovița, on which are numerous buildings of historical value from the time when it was crossed by the Bridge of Earth (the current Calea Plevnei).

University Terrace is a large terrace which is located in the central part of the city and has numerous tourist attractions such as: University, Şuțu Palace, National Military Club, National Bank Museum, CEC Palace, National Museum of History, Stravopoleos Church, Russian Church, Palace of the Ministry of Architecture, National Theater, Colțea Church, Colțea Palace.

Dâmboviței Meadow with widths of miles, has often suffered floods (the neighborhoods Eroilor, Grozăvești, Vitan, etc.) (Mihăilescu 1915, 1942) until the course of the river was regularized. Here are many tourist attractions such as: Botanical Garden, Romanian Opera, Cismigiu Park, Crețulescu Palace, Palace of Justice, Old Court, Saint Spiridon Church, Antim Ivireanul Church.

Of great importance in finalizing our approach is the knowledge of Bucharest population opinion on the geomorphological heritage of the city and the anthropic sites that are related to it, namely the geotourism routes that can be created.

\section{Data related to the relief of Bucharest}

Before having been interviewed, all the questioned persons were explained the terms used in the survey respectively the content of each variable (scientific, cultural, aesthetic, economic).

All subjects who answered the questions know representative forms of relief in the city of Bucharest (no geomorphosites were named in

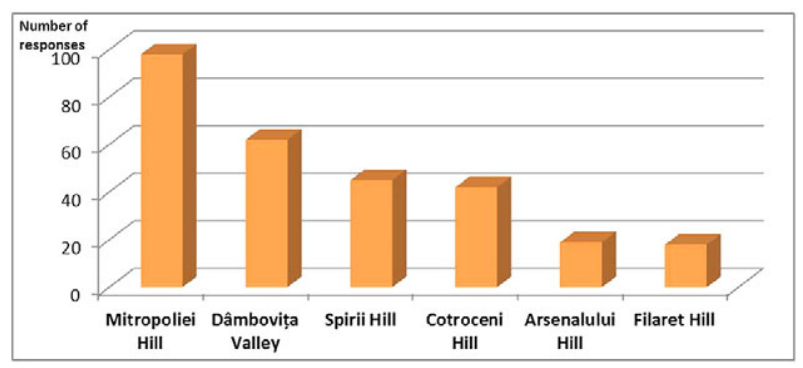

Fig. 4. The most important geomorphosites in Bucharest city.

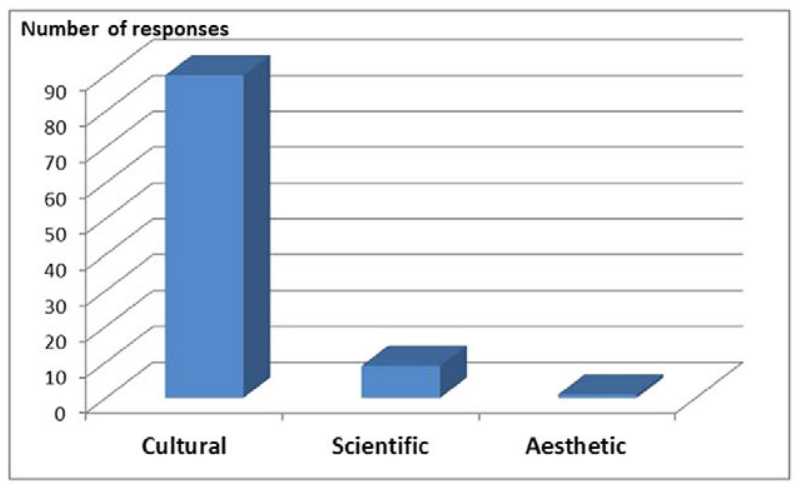

Fig. 5. The perception of population about geomorphosites value.

the questionnaire to avoid confusion), the most frequent geomorphosites (multiple variants were admitted, 284 answers) were represented by Mitropoliei Hill, Dambovita Valley (taken as a whole) and Spirii Hill (Fig. 4). Subjects grant to these landforms, to a small extent $(9 \%)$ a scientific value, but $90 \%$ consider that they have a significant cultural value linked to the existence of objectives (Parliament Palace, historical buildings or places of worship). The aesthetic value is known only by $1 \%$ of the respondents (Fig. 5). The interviewed persons noticed an existing connection between the forms of relief and some attractions with cultural function.

Regarding the changes that took place in Bucharest relief, all the subjects know about the regulation of Dâmbovița River and the works that took place in its meadow, only $4 \%$ mentioned the leveling and displacement works that took place during the communist period in order to be realized the urban reshaping.

\section{Data on the proposed tourist objectives and routes}

Regarding the assessment of important elements for tourism activity (multiple answers 


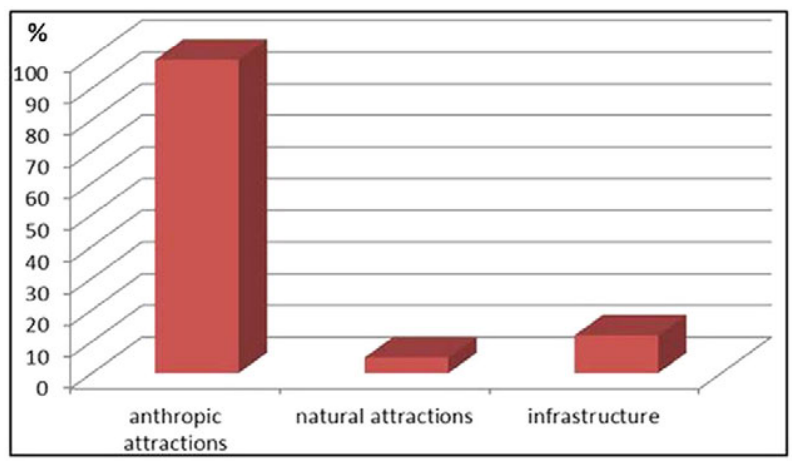

Fig. 6. The opinion of population about attractivity touristic elements in Bucharest city.

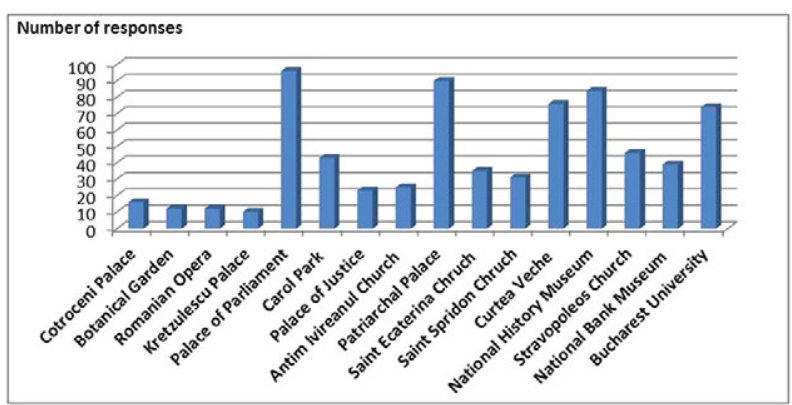

Fig. 7. The touristic elements proposed to be included in itineraries.

were allowed, 116 responses), the subjects appreciate first the anthropic components (99\%), and the natural ones (5\%) and the infrastructure (12\%) (Fig. 6) are less mentioned.

The interviewed subjects believe that local and central authorities should do more for the development of tourism in the city of Bucharest, among the measures they propose to include are: the restoration of the old city center, the establishment of pedestrian streets (such as Calea Victoriei), revitalization of the tourist bus, building tourist information centers equipped with promotional materials,

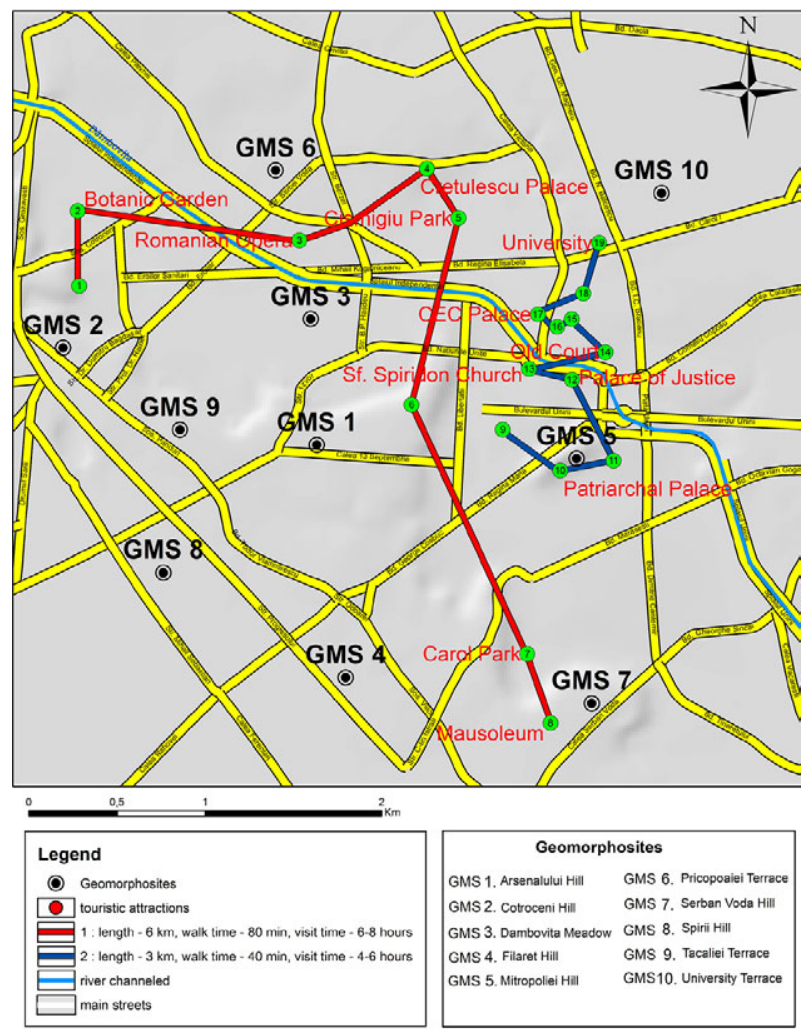

Fig. 8. The map of proposed geotouristic itineraries.

designing specialized tourist guides in recognized publishers, popularizing the city as a tourist destination on the Internet and making partnerships with travel agencies. The creation of geotourist routes, with a specialized guide, is positively appreciated by the questioned subjects. Figure 7 are shown the tourism objectives proposed to be included in itineraries (multiple responses were allowed, 712 answers), with a clear dominance for the Parliament Palace, the Patriarchal Palace, the National History Museum and the Old Court.

Taking into account the previous stages of the study, the relationship between the

Table 3. The main characteristics of proposed geotourism routes.

\begin{tabular}{|l|c|c|c|c|c|}
\hline \multicolumn{1}{|c|}{ Routes } & $\begin{array}{c}\text { Lenght } \\
(\mathrm{km})\end{array}$ & $\begin{array}{c}\text { Travel } \\
\text { time }\end{array}$ & $\begin{array}{c}\text { Visiting } \\
\text { time }\end{array}$ & Difficulty & \multicolumn{1}{c|}{ Geomorphosites } \\
\hline $\begin{array}{l}\text { Red - Cotroceni Palace (1) - Botanical Garden (2) - Ro- } \\
\text { manian Opera (3) - Kretzulescu Palace (4) - Cismigiu } \\
\text { Park (5) - Palace of Parliament (6) - Carol Park includ- } \\
\text { ing (7) - the Mausoleum and (8) - Suter Palace }\end{array}$ & 6 & $80 \mathrm{~min}$ & $6-8 \mathrm{~h}$ & Easy & $\begin{array}{l}\text { Cotroceni Hill, } \\
\text { Dâmbovița Meadow, } \\
\text { Procopoaia Terrace, } \\
\text { Spirii Hill, Filaret Hill }\end{array}$ \\
\hline $\begin{array}{l}\text { Blue - Antim Ivireanul Church (9) - Patriarchal Palace } \\
(10) \text { - Saint Ecaterina Chruch (11) - Palace of Justice } \\
(12) \text { - Saint Spridon Chruch (13) - Curtea Veche Muse- } \\
\text { um and Church (14) - Stravopoleos Church (15) - Na- } \\
\text { tional History Museum (16) - National Bank Museum } \\
(17) \text { - Bucharest University (18) }\end{array}$ & 3 & 40 min & $4-6 \mathrm{~h}$ & Easy & $\begin{array}{l}\text { Dâmbovița Meadow, } \\
\text { Mitropoliei Hill, Uni- } \\
\text { versity Terrace }\end{array}$ \\
\hline
\end{tabular}


geomorphosites and the anthropic tourist sites as well as the opinion of the population, two geotourism routes (Fig. 8) were established, the main characteristics of which are summarized in Table 3. In Romania, neither for Bucharest nor for other urban areas, geotourism maps have not been made and such tours have not been proposed. These are the first proposals for such routes which try to cover both the existing and inventoried geomorphosites within the central part of Bucharest city and the main cultural tourist attractions located in this area.

It is necessary to popularize them as well as to create a specialized website, from which tourists can access the information in real time.

\section{Conclusions}

This study is the starting point for a larger process aimed at the inventory and evaluation of geomorphosites both in the city of Bucharest and other important tourist cities of Romania (Iaşi, Cluj Napoca, Braşov, Sibiu, Constanța, Timişoara, Suceava, Sighişoara etc). The main purpose is to make them known and popularized, to highlight their scientific (including educational), aesthetic and cultural value.

At Romania's level, it is necessary to carry out projects on this topic by local / national authorities in the field and public - private partnerships, respectively between academic and decision-makers, for the exploitation of components related to geoheritage, geotourism and geoconservation, in order to minimize the risks that may occur and maximize opportunities for local communities and tourists.

The city of Bucharest has a remarkable geomorphological heritage, which is insufficiently capitalized, so it is necessary in a next stage to create a geotourism map for the central part (where the natural objectives are mixed with the anthropic ones) and some promotional materials (including on-line). The objectives of these materials are to give geotourism consistency, to promote geodiversity and to formulate conceptions and attitudes related to geoeducation to residents and tourists. Many respondents in Bucharest recognize and appreciate the value of geomorphosites. The development of urban tourism and of geotourism in Bucharest must also take into account the planning projects that are being implemented, the principles governing urban development.

\section{Acknowledgements}

The authors' contributions are equal. The authors want to thank their colleague Gabriel Stănoiu for his support in accomplishing the graphical part of this article.

\section{References}

Andrășanu A., 1996. Romania`s, legislation, NGOs and publications concerning the conservation of the geological heritage. Geologica Balcanica 26: 156-160.

Andrăşanu A., Grigorescu D., 2012. Geoheritage in Romania and its conservation, in Geoheritage in Europe and its conservation. In Wimbledon W., Smith-Meyer S. (ed), ProGEO. 1: 151-163.

Artugyan L., 2016. Geomorphosites assessment in karst terrains: Anina Karst Region (Banat Mountains, Romania). Geoheritage. DOI 10.1007/s12371-016-0188-x.

Bădăuță A., Cicio-Pop Al., 1935. Ghidul Bucureștilor. Editura Ghidul României, București.

Bâca I., 2011. Contribution to inventory and assessement of the geomorphosites in Călimani National Park. Case study: Bistricior Massif. Analele Universității din Oradea 1: 5-15.

Bâca I., Schuster E., 2011. Listing, evaluation and touristic utilisation of geosites with archaeological artefacts. Case study: Ciceu Ridge (Bistrița-Năsăud County, Romania). Revista Geografica Academica 5(1): 5-20.

Bâca I., 2012. The inventory, evaluation and tourist exploatation of some geosites with archaeological vestiges from Bistrita-Nasaud County. Case study: The Roman`s Road from Bârgău Mountains. Geojournal of Tourism and Geosites 9(2): $52-62$.

Berindei D., Bonifaciu S., 1978. București. Ghid turistic. Editura Sport-Turism, București.

Bruschi V.M., Cendrero A., 2005. Geosite evaluation; can we measure intangible values? Il Quaternario 18 (1): 293-306.

Bussard J., Reynard E., 2014. Assessment and protection of geomorphological heritage in the Gruyère - Pays-d'Enhaut Regional Nature Park (Switzerland).EGU General Assembly, 27 April - 2 May, Vienna, Austria.

Cantacuzino Ș., 1997. Două Orașe Distincte. Revista Secolul XX 4/6: 11-40.

Cocean G., Surdeanu V., 2011. The Assessement of geomorphosites of Touristic Interest in the Trascău Mountains. Studia Universitatis Babeș-Bolyai Geographia LVI (2): 67-81.

Cocean G., Cocean P., 2017. An assessment of gorges for Purposes of Identifying Geomorphosites of Geotourism Value in the Apuseni Mountains (Romania). Geoheritage 9 (1): 71-81. DOI 10.1007/s12371-016-0180-5.

Cocoș O., 1999. Sisteme hidrografice și gestionarea apei în municipiul București. Edition du Goeland, București.

Comănescu L., Dobre R., 2009. Inventorying, evaluating and tourism valuating the geomorphosites from the Central sector of the Ceahlău national park. GeoJournal of Tourism and Geosites II (1): 86-96.

Comănescu L., Nedelea A., Dobre R., 2009. Inventoring and Evaluation of Geomorphosites in the Bucegi Mountains. 
Forum Geografic. Studii și Cercetări de Geografie și Protecția Mediului, 8 (8): 38-44.

Comănescu L., Nedelea A., 2010. Analysis of some representative geomorphosites in the Bucegi Mountains: between scientific evaluation and tourist perception. Area 42 (4): 406-416. DOI 10.1111/j.1475-4762.2010.00937.x.

Comănescu L., Dobre R., Nedelea, A., 2011a. The identification of geomorphosites in different cartographic materials. The study cas- Bucegi Mts (Romania). The Egyptian Journal of Environmental Change 3 (1): 25-33.

Comănescu L., Nedelea A., Dobre R., 2011b. Evaluation of geomorphosites in Vistea Valley (Făgăraș Mountains-Carpathians, Romania). International Journal of the Physical Sciences 6(5): 1161-1168.

Comănescu L., Nedelea A., Dobre R., 2012. The evaluation of geomorphosites from Ponoare protected Area. Geographical Forum - Geographical Studies and Environment Protection Research 11(1): 54-61.

Comănescu L., Nedelea A., Dobre R., 2013. The geotouristic map - between theory and practical use. Case study - The central sector of the Bucegi Mountains (Romania). GeoJournal of Tourism and Geosites VI (1): 16-22.

Coratza P., Giusti C., 2005. Methodological proposal for the assessment of the scientific quality of geomorphosites. Il Quaternario 18 (1): 307-314.

Dumitrescu E., 1971. Clima orașului București. Teză de doctorat, Universitatea din București.

Enciu P., Bălteanu, D., Dragotă C., Grigorescu I., Dumitrică C., Popescu D.C., 2008. Cadrul natural al municipiului București și a zonelor înconjurătoare. In Lăcătuşu R., Popescu M., Atansiu N., Enciu P (ed), Geoatlasul municipiului București. Editura EstFalia, București.

Gavrilă I. G., Man, T., Surdeanu, V., 2011. Geomorphological heritage assessement using GIS analyses for geotourism development in Măcin Mountains, Dobrogea, Romania. GeoJournal of Tourism and Geosites IV (2): 198-205.

Georgescu F., Cernovodeanu P., Cebuc A., (1966). Monumente din București. Editura Meridiane, București.

Giurescu C., 1966. Istoria Bucureștilor. Din cele mai vechi timpuri pînă în zilele noastre, Editura Pentru Literatură, București.

Grecu F., Zaharia L., Ghiță C., Comănescu L., Cîrciumaru E., Albu M., 2012. Sisteme hidrogeomorfologice din Câmpia Română, Hazard- Vulnerabilitate- Risc. Editura Universității din București, București.

Grigorescu D., Andrășanu A., Csiki Z., 2003. Geological Heritage Conservation and regional development strategies for the South Eastern European Countries. ProGEO Workshop Guide. Editura Ars Docendi, București.

Iancu M., 1977. Geografia industriei Municipiului București și a Județului Ilfov. Teză de doctorat, Universitatea din București.

Ilieș D. C, Josan N., 2007. Preliminary contribution to the investigation of the Geosites from Apuseni Mountains (Romania). Revista de Geomorfologie 9: 53-59.

Ilieş D. C., Josan N., 2009. Geosituri şi geopeisaje. Editura Universitătii din Oradea, Oradea.

Ilieș D. C., Blaga L., Hodor N., Josan I., Gozner M., 2009. Estimation of the Geomorphostructures with geomorphosite valence in the northern part of Hunedoara county (Western Romania). Analele Universității din Oradea- Geografie XIX: 41-46

Ilieș D. C., Ilies A., Herman G., Baias S., Morar C., 2011. Geotourist map of the Baile Felix-Baile 1 Mai-Betfia area (Bihor County, Romania). GeoJournal of Tourism and Geosites IV (2): 219-227.
Ionescu G., 1938. București. Ghid istoric și artistic. Fundația pentru literatură și artă, Regele Carol II, București.

Ionesi L., 1994. Geologia unităților de platformă și a orogenului nord-dobrogean. Editura Tehnică, București.

Liteanu E., 1952. Geologia zonei orașului București. Comitetul Geologic, Studii tehnice și economice- Hidrogeologie, seria $\mathrm{E}, 1$.

Manoleli D., Gildean N., Andrășanu A., Rusti D., Gheorghe I., 2003. The Assessment of the national inventory for sites in order to facilitate the selection of special conservation areas to be proposed in the Natura 2000 Network (Directives 92). IER, București.

Mihăilescu V., 1915. Bucureștii din punct de vedere antropogeografic și etnografic. Anuarul de Geografie și antropogeografie al Seminarului geografic IV.

Mihăilescu V., 1942. București. Natura.

Pereira L. S., 2017. Potential geomorphosites as locals of geotouristic interest: Case of municipality of João Pessoa, Paraíba State (Brazilian NE). GeoJournal of Tourism and Geosites X(1): 7-21.

Pereira P., Pereira D., 2010. Methodological guidelines for geomorphosite assessment. Géomorphologie: relief, processus, environnement 16 (2): 215-222.

Pica A., Vergari F., Fredi P., Del Monte M., 2016. The Aeterna Urbs Geomorphological Heritage (Rome, Italy). Geoheritage, 8 (1): 31-42. DOI:10.1007/s12371-015-0150-3.

Pica A., Reynard E., Grangier L., Kaiser C., Ghiraldi L., Perotti L., Del Monte M., 2017. GeoGuides, Urban Geotourism Offer Powered by Mobile Application Technology. Geoheritage. DOI: 10.1007/s12371-017-0237-0.

Pinto C., Vicente J., Pinto M., Santo G.E., Munoz M., Moitinho I., 2011. Inventory, dissemination and preservation of the geological heritage in urban areas - Lisbon City Case Study. GeoJournal of Tourism and Geosites IV (2): 263-272.

Posea G., Ştefănescu I., 1984. Municipiul Bucureşti cu Sectorul Agricol Ilfov. Editura Academiei, București.

Pralong J.P., 2005. A method for assessing tourist potential and use of geomorphological sites. Géomorphologie: relief, processus, environnement 3: 189-196.

Purice C., Romanescu Gh., Romanescu G., 2013. The protection of the geomorphosites within the Măcin Mountains National Park (Romania) and their touristic importance. International Journal of Conservation Science 4 (3): 373-383.

Reynard E., Fontana G., Kozlik L, Scapozza C., 2007. A method for assessing «scientific» and «additional values» of geomorphosites. Geographica Helvetica 62 (3): 148-158.

Reynard E., Coratza P., Regolini-Bissig G., 2009. Geomorphosites. Verlag Dr. Friedrich Pfeil, Munchen.

Reynard E., Perret A., Bussard J., Grangier L., Martin S., 2016. Integrated Approach for the Inventory and Management of Geomorphological Heritage at the Regional Scale. Geoheritage 8 (1): 43-60.

Rodriques M. L., Machado C. R., Freire E., 2011. Geotourism Routes in urban areas: A preliminary approach to the Lisbon geoheritage survey. GeoJournal of Tourism and Geosites IV (2): 281-295

Serrano E., Gonzalez-Trueba J.J., 2005. Assessment of geomorphosites in natural protected areas: the Pico de Europa National Park (Spain). Géomorphologie: relief, processus, environnement 3: 197-208.

Stematiu D., Teodorescu D., 2012. Râul Dâmbovita în Bucureşti - sistemul de apărare împotriva inundațiilor. $\mathrm{Lu}$ crările ediției a VII-a a conferinței anuale "Zilele Acádemice ale A.S.T.R"11-12 octombrie 2012: 143-150. 